University of South Florida

DIGITAL COMMONS

Digital Commons @ University of

@ UNIVERSITY OF SOUTH FLORIDA

South Florida

School of Geosciences Faculty and Staff

Publications

School of Geosciences

9-2017

\title{
Catchment-Scale Alder Cover Controls Nitrogen Fixation in Boreal Headwater Streams
}

\author{
Daniel L. Hiatt \\ Baylor University \\ Caleb J. Robbins \\ Baylor University \\ Jeffrey A. Back \\ Baylor University \\ Pamela K. Kostka \\ Baylor University \\ Robert D. Doyle \\ Baylor University
}

See next page for additional authors

Follow this and additional works at: https://digitalcommons.usf.edu/geo_facpub

Part of the Earth Sciences Commons

\section{Scholar Commons Citation}

Hiatt, Daniel L.; Robbins, Caleb J.; Back, Jeffrey A.; Kostka, Pamela K.; Doyle, Robert D.; Walker, Coowe M.; Rains, Mark C.; Whigham, Dennis F.; and King, Ryan S., "Catchment-Scale Alder Cover Controls Nitrogen Fixation in Boreal Headwater Streams" (2017). School of Geosciences Faculty and Staff Publications. 1218.

https://digitalcommons.usf.edu/geo_facpub/1218

This Article is brought to you for free and open access by the School of Geosciences at Digital Commons @ University of South Florida. It has been accepted for inclusion in School of Geosciences Faculty and Staff Publications by an authorized administrator of Digital Commons @ University of South Florida. For more information, please contact digitalcommons@usf.edu. 


\section{Authors}

Daniel L. Hiatt, Caleb J. Robbins, Jeffrey A. Back, Pamela K. Kostka, Robert D. Doyle, Coowe M. Walker, Mark C. Rains, Dennis F. Whigham, and Ryan S. King 


\title{
Catchment-scale alder cover controls nitrogen fixation in boreal headwater streams
}

\author{
Daniel L. Hiatt ${ }^{1,5,7}$, Caleb J. Robbins ${ }^{1,8}$, Jeffrey A. Back ${ }^{1,9}$, Pamela K. Kostka ${ }^{1,6,10}$, Robert D. Doyle ${ }^{1,11}$, \\ Coowe M. Walker ${ }^{2,12}$, Mark C. Rains ${ }^{3,13}$, Dennis F. Whigham ${ }^{4,14}$, and Ryan S. King ${ }^{1,15}$ \\ ${ }^{1}$ Center for Reservoir and Aquatic Systems Research, Department of Biology, Baylor University, One Bear Place 97388, Waco, Texas \\ 76798 USA \\ ${ }^{2}$ Kachemak Bay Research Reserve, 95 Sterling Highway, Suite 2, Homer, Alaska 99603 USA \\ ${ }^{3}$ School of Geosciences, University of South Florida, 4202 E. Fowler Avenue, Tampa, Florida 33559 USA \\ ${ }^{4}$ Smithsonian Environmental Research Center, P.O. Box 28, 647 Contees Wharf Road, Edgewater, Maryland 21037 USA \\ ${ }^{5}$ Department of Crop Sciences, University of Illinois, 1102 South Goodwin Avenue, Urbana, Illinois 61801 USA \\ ${ }^{6}$ Department of the Army, US Army Corps of Engineers, Regulatory Division, 915 Wilshire Boulevard, Suite 930, Los Angeles, California \\ 90017 USA
}

\begin{abstract}
Alder (Alnus spp.) is a woody plant with bacterial symbionts that fix atmospheric $\mathrm{N}_{2}$ into bioavailable $\mathrm{N}$. We studied 12 North American boreal headwater streams spanning a steep gradient of catchment alder cover $(0-$ $27 \%$ ) to test the hypothesis that increasing inputs of inorganic $\mathrm{N}$ associated with increasing alder cover would reduce or eliminate in-stream benthic $\mathrm{N}_{2}$ fixation. We measured $\mathrm{N}_{2}$ fixation rates, chlorophyll $a$, and ash-free dry mass (AFDM) of periphyton in early (May) and late (August) summer 2011. Dissolved inorganic N (DIN) concentrations, composed almost entirely of $\mathrm{NO}_{3} / \mathrm{NO}_{2}-\mathrm{N}$, ranged from below detection limits to nearly $2 \mathrm{mg} / \mathrm{L}$ and were strongly predicted by catchment alder cover in both months. Higher $\mathrm{N}_{2}$ fixation rates were observed in August than in May. $\mathrm{N}_{2}$ fixation rates declined sharply when alder cover exceeded $\sim 2 \%$ of catchment cover, corresponding to 20 to $40 \mu \mathrm{g} / \mathrm{L}$ DIN. This pattern also was evident among 3 streams with contrasting catchment alder cover sampled approximately every 2 wk during the study. The stream with no catchment alder cover exhibited a steady increase in $\mathrm{N}_{2}$ fixation rates over the summer, whereas the streams with low and high alder in their catchments had very low $\mathrm{N}_{2}$ fixation rates that did not vary over time. The influence of alder cover on periphyton biomass was not clear. The strong regulation of alder cover on in-stream $\mathrm{N}$ availability leads us to suggest that alder presence may be an important terrestrial regulator of stream $\mathrm{N}$ cycling.
\end{abstract}

Key words: nitrogen fixation, terrestrial-aquatic linkages, benthic primary production, nutrients, Kenai Peninsula, Alaska

Stream ecosystem function depends on the delivery and availability of allochthonous resources (Polis et al. 1997). In particular, landscape-derived nutrients subsidize stream microbes, facilitating many important ecosystem functions, such as litter decomposition, nutrient cycling, and secondary production (Allan and Castillo 2007). Thus, identifying tight linkages between landscape-scale factors and stream ecosystem processes is highly valuable for general understanding of stream ecosystems.

Alder (Alnus spp.) is a common tree or shrub throughout northern latitudes of the world. Alder is actinorhizal, forming a symbiosis with bacteria (Frankia). This symbiont fixes $\mathrm{N}_{2}$ (atmospheric $\mathrm{N}_{2}$ ) into bioavailable forms, resulting in leaching of inorganic $\mathrm{N}\left(\right.$ as $\mathrm{NO}_{3}{ }^{-}$or $\mathrm{NH}_{4}{ }^{+}$) into soil below alder stands (Rothe et al. 2002, Edmonds and Tuttle 2010). Large stands of alder can saturate the $\mathrm{N}$ demand of soil microbes (Bühlmann et al. 2016), resulting in export of excess $\mathrm{N}$ to streams (Stottlemyer and Toczydlowski 1999, Compton et al. 2003, Shaftel et al. 2011, 2012). Stream $\mathrm{N}$ subsidies from catchment-scale alder are expected to be ecologically influential (Hiltbrunner et al. 2014), and catchment alder-derived dissolved inorganic N (DIN) can

E-mail addresses: ${ }^{7}$ dhiatt@illinois.edu; ${ }^{8}$ caleb_robbins@baylor.edu; ${ }^{9}$ jeff_back@baylor.edu; ${ }^{10}$ pamela.k.kostka@usace.army.mil; ${ }^{11}$ robert_doyle@baylor .edu; ${ }^{12}$ cmwalker9@uaa.alaska.edu; ${ }^{13}$ mrains@usf.edu; ${ }^{14}$ whighamd@si.edu; ${ }^{15}$ ryan_s_king@baylor.edu

Correction: This article was corrected and reposted on June 20, 2017, with a correction to the $x$-axis labels in Figure 2.

DOI: 10.1086/692944. Received 8 December 2016; Accepted 18 April 2017; Published online 14 June 2017.

Freshwater Science. 2017. 36(3):523-532. ๑ 2017 by The Society for Freshwater Science. 
drive patterns in leaf-litter decomposition and associated macroinvertebrate community composition (Shaftel et al. 2011). However, studies elucidating the influence of alderderived $\mathrm{N}$ on steam ecosystems are still lacking, and some riparian $\mathrm{N}_{2}$ fixers can alleviate autotrophic $\mathrm{N}$ limitation but unexpectedly increase reach-scale demand for inorganic $\mathrm{N}$ (Mineau et al. 2011). This situation highlights the uncertainty surrounding the effect of terrestrial $\mathrm{N}_{2}$ fixers on aquatic nutrient cycling. The influence of alder-derived $\mathrm{N}$ on streams may be important in boreal systems, where $\mathrm{N}$ is frequently a limiting nutrient (Burrows et al. 2015, LeBauer and Treseder 2008).

In addition to being ubiquitous in alder, $\mathrm{N}_{2}$ fixation can be accomplished in streams by cyanobacteria or diatoms with cyanobacterial endosymbionts (Marcarelli and Wurtsbaugh 2006, Kunza and Hall 2013). Acquiring N via $\mathrm{N}_{2}$ fixation is energetically costly compared to inorganic $\mathrm{N}$ uptake (Howarth et al. 1988, Vitousek et al. 2002), so low DIN $\left(\mathrm{NO}_{3}-\mathrm{N}+\mathrm{NO}_{2}-\mathrm{N}+\mathrm{NH}_{4}-\mathrm{N}\right)$ concentrations strongly favor microbial $\mathrm{N}_{2}$ fixers and increase aquatic $\mathrm{N}_{2}$ fixation rates (Howarth et al. 1988, Marcarelli and Wurtsbaugh 2006, Scott et al. 2009, Lang et al. 2012, Kunza and Hall 2013). DIN is recognized as a critical control on in-stream $\mathrm{N}_{2}$ fixation rates (Howarth et al. 1988). In the absence of other limitations, $\mathrm{N}_{2}$ fixation could facilitate primary production by supplying bioavailable $\mathrm{N}$ necessary for growth, especially in pristine streams where $\mathrm{N}_{2}$ fixation can exceed DIN uptake (Kunza and Hall 2014). Determining how prominent landscape components control the rates and spatial distribution of $\mathrm{N}_{2}$ fixation is critical for understanding basic ecosystem functioning and forecasting stream responses to landscape changes (Vitousek et al. 2002), especially in regions where anthropogenic $\mathrm{N}$ inputs are limited (Sobota et al. 2013).

We examined the influence of alder on stream $\mathrm{N}_{2}$ fixation rates and periphytic biomass across a gradient of alder cover in 12 boreal headwater streams with minimal human disturbance in the catchments. Previous research in this area has shown that alder cover can determine stream DIN concentrations (Shaftel et al. 2012). Because $\mathrm{N}_{2}$ fixation rates in pristine streams are largely determined by $\mathrm{N}$ availability in the absence of other limiting factors, we expected that alder cover would control stream $\mathrm{N}_{2}$ fixation rates via DIN inputs. Specifically, we hypothesized that higher alder cover would lead to high stream DIN concentrations, in turn inhibiting in-stream $\mathrm{N}_{2}$ fixation rates.

\section{METHODS}

\section{Study sites}

Our study streams are situated on the Kenai Peninsula in south-central Alaska (Fig. 1). The Kenai Peninsula is sparsely populated and supports extremely limited agriculture. As a result, any fertilization effects were negligible in the study streams and were not expected to confound our results. The sparse population in the region limits the influence of $\mathrm{N}$ deposition driven by anthropogenic activities. Vegetation consists of mixed forests dominated by lutz spruce (Picea lutzii) and paper birch (Betula papyrifera), interspersed with willow (Salix spp.) and alder (Alnus spp.) thickets and meadows dominated by bluejoint (Calamagrostis canadensis) and fireweed (Chamerion angustifolium) (Reynolds 1990, Viereck et al. 1992). Wetlands cover much of the region and some, but not all, of these wetlands are large peatlands, dominated by Sphagnum spp. and dwarf birch (Betula nana) (Gracz and Glaser 2016).

To estimate in-stream $\mathrm{N}$ concentrations and $\mathrm{N}_{2}$ fixation rates, we conducted a spatial study of 12 low-order streams spread across 4 different river drainages in May 2011 to capture the early season concentrations of DIN from headwater streams. We chose sampling locations in each stream that had predominantly cobble substrate and were open canopied. Low-order streams in this region are predominantly lined with grass (C. canadensis) rather than shrubs or trees, which are much more common in upland areas, so direct canopy cover is minimal. Nevertheless, we avoided locations with overhanging vegetation and undercut banks. We resampled 10 of the 12 streams in August (2 sites were not accessible) during late-summer baseflow conditions when stream temperatures and DIN concentrations should have been near annual maxima and minima, respectively (Table 1 ). The streams spanned a moderate range of catchment size $\left(2.4-12.6 \mathrm{~km}^{2}\right)$, but spanned a large range of catchment alder cover (0-27\%). We identified alder stands on color satellite images in a geographic information system (GIS), and calculated polygons for each stand (including riparian and stands located further upland). Percent cover of the entire watershed was estimated based on the polygon sizes of mapped alder stands. Alder-stand mapping and physical presence and accuracy were validated by Shaftel et al. (2012).

We selected 3 of the 12 streams for approximately biweekly monitoring between May and August (temporal sites) to characterize temporal trends in nutrient availability, periphyton biomass, and enzyme activity. We sampled temporal sites 7 times from May to August, whereas we sampled the other 9 sites once in May and once in August. Catchments associated with the temporal sites had no (STAR-171: 0\%), low (ANC-1203: 10.5\%) and high catchment alder cover (ANC-5; 26.7\%) (Table 1). Sampling occurred in these 3 streams on weeks $1,2,4,6,8$, and 10 of the study.

\section{Stream chemistry}

We collected and analyzed water for $\mathrm{NO}_{3} / \mathrm{NO}_{2}-\mathrm{N}$, $\mathrm{NH}_{4}-\mathrm{N}$, and $\mathrm{PO}_{4}-\mathrm{P}$ on each site visit. We did not expect $\mathrm{PO}_{4}-\mathrm{P}$ to drive $\mathrm{N}_{2}$ fixation because it is in relatively high concentrations throughout the study area streams because 


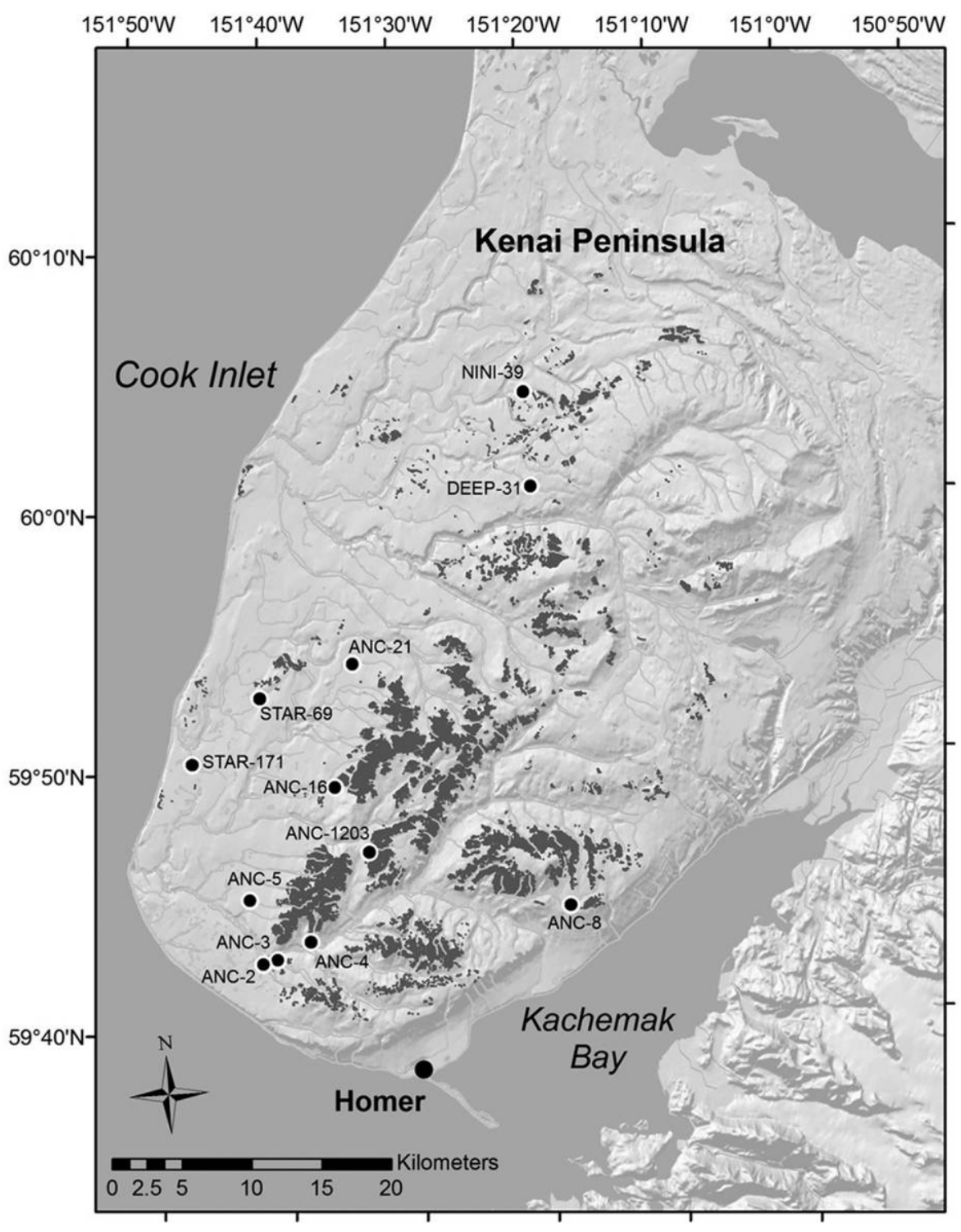

Figure 1. Regional map of the lower Kenai Peninsula, Alaska, illustrating stream locations and alder cover (denoted by dark gray fill on hillslopes).

of widespread volcanic deposition resulting in soils rich in P (Dugdale and Dugdale 1961, Ping and Michaelson 1986).

We filtered dissolved samples in the field with a $0.45-\mu \mathrm{m}$ filter and syringe (Monoject ${ }^{\circledR}$ Syringe with Luer Lock; Tyco Healthcare Group, Mansfield, Massachusetts; $0.45-\mu \mathrm{m}$ Whatman Syringe Filters, GE Healthcare, Pittsburgh, Pennsylvania). We stored water samples on ice immediately after collection and froze them upon returning to the laboratory. We shipped samples weekly by overnight delivery to Baylor University where they were stored frozen until analysis (samples were processed within $20 \mathrm{~d}$ of collection). $\mathrm{NO}_{3} /$ $\mathrm{NO}_{2}-\mathrm{N}, \mathrm{NH}_{4}-\mathrm{N}$, and $\mathrm{PO}_{4}-\mathrm{P}$ were analyzed according to QuikChem methods (total P [TP]/dissolved P: method 10-115-01-1-F, $\mathrm{NH}_{4}-\mathrm{N}$ : method 10-107-106-1-J, total $\mathrm{N}$ [TN]/dissolved N: method 10-107-04-1-J) on a flow- injection auto-analyzer (Lachat QuikChem 8500 series 2 FIA and Series 520 XYZ Autosampler; Hach, Loveland, Colorado). We measured temperature, $\mathrm{pH}$, dissolved $\mathrm{O}_{2}$ (DO), and specific conductance (Table 1) in situ with a YSI 556 MPS (Yellow Springs Instruments, Yellow Springs, Ohio). We took instantaneous discharge measurements during each visit with a top-setting wading rod and Marsh-McBirney Flo-Mate flow meter (Hach, Loveland, Colorado).

\section{Enzyme activity}

We measured $\mathrm{N}_{2}$ fixation rates of benthic periphyton with the acetylene-reduction method (Flett et al. 1976). The basis for this method is that $\mathrm{N}_{2}$ fixing bacteria readily use acetylene gas $\left(\mathrm{C}_{2} \mathrm{H}_{2}\right)$ in place of $\mathrm{N}_{2}$ and produce ethyl- 
Table 1. Catchment \% alder cover, stream nutrient concentrations, and other in-stream characteristics, and benthic ash-free dry mass (AFDM) and chlorophyll $a$ (CHLA) values corresponding to the study sites. Temporal intensive sampling sites are bolded. $-=$ missing data caused by multiprobe failure. Sp. cond. $=$ specific conductance, $\mathrm{T}=$ temperature.

\begin{tabular}{|c|c|c|c|c|c|c|c|c|c|c|c|}
\hline Site & $\begin{array}{c}\text { Alder cover } \\
(\%)\end{array}$ & $\begin{array}{c}\mathrm{NH}_{4}-\mathrm{N} \\
(\mu \mathrm{g} / \mathrm{L})\end{array}$ & $\begin{array}{c}\mathrm{NO}_{3}-\mathrm{N} / \mathrm{NO}_{2}-\mathrm{N} \\
(\mu \mathrm{g} / \mathrm{L})\end{array}$ & $\begin{array}{l}\mathrm{PO}_{4}-\mathrm{P} \\
(\mu \mathrm{g} / \mathrm{L})\end{array}$ & $\mathrm{T}\left({ }^{\circ} \mathrm{C}\right)$ & $\mathrm{pH}$ & $\begin{array}{l}\text { Sp. Cond. } \\
(\mu \mathrm{S} / \mathrm{cm})\end{array}$ & $\begin{array}{c}\text { Discharge } \\
(\mathrm{L} / \mathrm{s})\end{array}$ & $\begin{array}{c}\text { AFDM } \\
\left(\mathrm{mg} / \mathrm{cm}^{2}\right)\end{array}$ & $\begin{array}{c}\text { CHLA } \\
\left(\mu \mathrm{g} / \mathrm{cm}^{2}\right)\end{array}$ & $\begin{array}{l}\text { Catchment } \\
\text { area }\left(\mathrm{km}^{2}\right)\end{array}$ \\
\hline \multicolumn{12}{|l|}{ May } \\
\hline DEEP-31 & 0.0 & 3.0 & 1.0 & 33.0 & 7.86 & 7.24 & 76 & 13.87 & 0.88 & 0.56 & 4.1 \\
\hline STAR-171 & 0.0 & 3.0 & 8.6 & 27.8 & 7.03 & 6.87 & 97 & 13.87 & 0.60 & 0.14 & 4.1 \\
\hline STAR-69 & 1.1 & 3.0 & 42.0 & 29.6 & 4.01 & 7.38 & 88 & 11.89 & 0.77 & 0.19 & 11.9 \\
\hline NINI-39 & 1.8 & 3.0 & 85.2 & 19.1 & 3.78 & 7.04 & 48 & 3.39 & 0.29 & 0.23 & 12.6 \\
\hline ANC-21 & 2.3 & 3.0 & 142.5 & 30.0 & 4.86 & 7.15 & 58 & 26.90 & 0.38 & 0.19 & 5.7 \\
\hline ANC-3 & 3.1 & 3.0 & 472.5 & 41.8 & 4.55 & 7.27 & 56 & 7.08 & 0.50 & 0.36 & 6.3 \\
\hline ANC-2 & 5.9 & 3.0 & 141.0 & 19.0 & 3.84 & 7.14 & 70 & 51.54 & 0.72 & 1.51 & 5.3 \\
\hline ANC-8 & 8.3 & 9.6 & 83.6 & 20.5 & 3.71 & 6.98 & 34 & 58.05 & 0.83 & 1.23 & 7.0 \\
\hline ANC-1203 & 10.5 & 3.0 & 464.0 & 51.1 & 4.55 & 7.27 & 56 & 9.91 & 0.74 & 0.42 & 3.3 \\
\hline ANC-4 & 18.7 & 3.0 & 1050.0 & 27.5 & 4.56 & 7.47 & 87 & 12.18 & 0.04 & 0.17 & 2.4 \\
\hline ANC-16 & 23.3 & 12.6 & 1230.0 & 42.2 & 4.93 & 7.48 & 69 & 19.54 & 0.47 & 0.37 & 4.0 \\
\hline ANC-5 & 26.7 & 6.9 & 1605.5 & 25.7 & 5.72 & 7.31 & 64 & 20.39 & 0.21 & 0.14 & 5.1 \\
\hline \multicolumn{12}{|l|}{ August } \\
\hline DEEP-31 & 0.0 & 3.0 & 1.7 & 30.9 & 8.08 & - & 77 & 7.93 & 1.08 & 1.36 & 4.1 \\
\hline STAR-171 & 0.0 & 3.0 & 1.0 & 20.1 & 6.42 & - & 84 & 21.52 & 2.21 & 1.66 & 4.1 \\
\hline NINI-39 & 1.8 & 3.0 & 108.5 & 20.8 & 4.67 & - & 47 & 2.83 & 0.93 & 1.14 & 12.6 \\
\hline ANC-3 & 3.1 & 3.0 & 27.3 & 14.2 & 6.80 & - & 56 & 23.23 & 0.85 & 0.74 & 6.3 \\
\hline ANC-2 & 5.9 & 3.0 & 46.8 & 57.9 & 6.59 & - & 54 & 58.05 & 1.40 & 3.13 & 5.3 \\
\hline ANC-8 & 8.3 & 3.0 & 42.2 & 39.1 & 7.27 & - & 41 & 50.40 & 0.44 & 0.42 & 7.0 \\
\hline ANC-1203 & 10.5 & 3.0 & 295.0 & 47.1 & 6.40 & - & 73 & 58.05 & 0.423 & 0.31 & 3.3 \\
\hline ANC-4 & 18.7 & 6.8 & 967.5 & 27.0 & 6.43 & - & 92 & 5.38 & 1.00 & 0.36 & 2.4 \\
\hline ANC-16 & 23.3 & 3.0 & 978.0 & 48.3 & 10.09 & - & 85 & 13.59 & 0.32 & 0.44 & 4.0 \\
\hline ANC-5 & 26.7 & 3.0 & 1071.5 & 26.5 & 8.24 & - & 63 & 19.26 & 0.78 & 1.52 & 5.1 \\
\hline
\end{tabular}

ene gas $\left(\mathrm{C}_{2} \mathrm{H}_{4}\right)$ as a byproduct. To simulate ambient conditions during our $\mathrm{N}_{2}$ fixation assays, we used a walk-in cooler maintained within $2^{\circ} \mathrm{C}$ of measured stream temperatures $\left(\sim 6^{\circ} \mathrm{C}\right.$; Table 1$)$. We chose these conditions to minimize community-driven changes and to ensure that temperature did not strongly influence our interpretation of how alder regulates $\mathrm{N}_{2}$ fixation via DIN inputs.

We performed preliminary trial incubations to identify the length of time for which $\mathrm{N}_{2}$ fixation assays should be conducted. The trial incubations ranged from 2.5 to $4.75 \mathrm{~d}$, and we collected subsamples approximately every 8-12 h. Temperature and light conditions were maintained constant during the trial incubations. We decided on an incubation time of $3.5 \mathrm{~d}$ because assays over this time period showed significant $\mathrm{N}_{2}$ fixation and maintained a linear relationship between ethylene production and time. This long incubation time may not reflect in situ conditions, but it provides accurate relative measurement of $\mathrm{N}_{2}$ fixation under light-saturated conditions.
In the field, we haphazardly collected 6 cobbles (64256- $\mathrm{mm}$ ) and filtered site water collected in triple-rinsed dark bottles from each stream. We wrapped each cobble individually in $\mathrm{Al}$ foil to avoid disruption of the periphyton, placed them on ice, and shipped them overnight to Baylor University for estimation of $\mathrm{N}_{2}$ fixation rates. In the laboratory, we placed cobbles in individual, airtight containers (250-mL mason jars) fitted with a rubber gasket to provide an airtight seal and a rubber septum to allow injection of $\mathrm{C}_{2} \mathrm{H}_{2}$ gas. We filled containers with $\geq 95 \mathrm{~mL}$ of filtered stream water (from the representative stream) up to the volume required to submerge the cobble. Cobble volume ranged from 15 to $80 \mathrm{~mL}$, so the vapor volume in the jars ranged from 75 to $140 \mathrm{~mL}$. We sealed jars and injected $\mathrm{C}_{2} \mathrm{H}_{2}$ gas into each container to provide an aqueous concentration of 0.10 to $0.13 \mathrm{~mL}$ a $\mathrm{C}_{2} \mathrm{H}_{2} / \mathrm{mL}$ water (typically 18-21 mL pure $\mathrm{C}_{2} \mathrm{H}_{2}$ by dissolving $\mathrm{CaCl}_{2}$ in deionized [DI] water), values sufficiently high to saturate $\mathrm{N}_{2}$ fixation (Flett el. al. 1976). Once jars were injected with $\mathrm{C}_{2} \mathrm{H}_{2}$, we 
swirled them gently for $\geq 3$ min to ensure complete equilibration between the headspace and the aqueous portion of the container. Once mixed, we vented the headspace to release pressure. For each stream, we placed 5 jars in light-saturating conditions (400-500 $\mu \mathrm{mol} \mathrm{m}^{-2} \mathrm{~s}^{-1}$ ) and wrapped 1 jar in $\mathrm{Al}$ foil to evaluate $\mathrm{N}_{2}$ fixation rates in the dark.

Following incubation, we removed $100 \mu \mathrm{L}$ of gas from the headspace of each container and analyzed it on a Shimadzu 2010 Gas Chromatograph (Shimadzu Scientific Instruments, Columbia, Maryland) equipped with a flame ionization detector and a 1.8-m column packed with $80 \%$ Porapack $\mathrm{N}$ and $20 \%$ Porapack Q. We used He as a carrier gas and maintained the oven at $80^{\circ} \mathrm{C}$. We used $12 \mathrm{mg} \mathrm{C}_{2} \mathrm{H}_{4} / \mathrm{L}$ ethylene standards (Scotty Analyzed Gases, Air Liquide America Specialty Gases, Plumsteadville, Pennsylvania) to calibrate the instrument each day. We incubated DI $+\mathrm{C}_{2} \mathrm{H}_{2}$ gas blanks with each sample round. $\mathrm{A}$ trace amount of $\mathrm{C}_{2} \mathrm{H}_{4}$ was found in these blanks $(0.2-$ $2.0 \mathrm{mg} / \mathrm{L}$ ), so sample values that fell within the $95 \% \mathrm{CI}$ of the blank's mean were considered below detection limits and treated as 0 . The detection limit for the method was $\sim 0.05 \mathrm{mg} \mathrm{L}^{-1} \mathrm{~d}^{-1}$ of $\mathrm{C}_{2} \mathrm{H}_{4}$ accumulation in the incubation vessel (corresponding to $\sim 5 \mathrm{ng} \mathrm{N} \mathrm{m}^{-2} \mathrm{~h}^{-1}$ under light-saturated conditions). We converted rates of $\mathrm{C}_{2} \mathrm{H}_{4}$ to $\mathrm{N}$ units based on the $3: 1$ theoretical molar ratio (Flett et. al. 1976), and standardized $\mathrm{N}_{2}$ fixation rates to the cobble surface area. We corrected for $\mathrm{C}_{2} \mathrm{H}_{4}$ solubility at the incubation temperature and aqueous: vapor phase volumes.

\section{Periphyton biomass}

We scrubbed periphyton from all cobbles and diluted the resulting slurry to a known volume. We used the periphyton slurry to estimate biomass as ash-free dry mass (AFDM) and chlorophyll $a$ (CHLA) following methods published by Biggs and Kilroy (2000). We used a Beckman DU series spectrophotometer (Beckman Coulter, Fullerton, California) to measure CHLA concentrations for each sample. We wrapped scraped rock surfaces with Al foil and weighed the foil to estimate surface area of the cobble with a foil mass-to-area relationship. We standardized AFDM and CHLA to surface area of cobbles (mg AFDM $/ \mathrm{cm}^{2}$ and $\mu \mathrm{g} \mathrm{CHLA} / \mathrm{cm}^{2}$ ).

\section{Data analysis}

We used generalized linear models (GLMs) in R (version 2.13.0; R Project for Statistical Computing, Vienna, Austria; Zuur et al. 2009) to analyze DIN, $\mathrm{N}_{2}$ fixation rates, AFDM, and CHLA in response to \% alder cover, and $\mathrm{N}_{2}$ fixation rates, AFDM, and CHLA in response to DIN from the spatial study. We fit separate GLMs for May $(n=12)$ and August $(n=10)$ because missing data from 2 sites in
August prevented inclusion of month as a main effect. With the exception of DIN, which was a single measurement per site per date, we used means of $\mathrm{N}_{2}$ fixation rates, AFDM, and CHLA as response values in the GLMs. We used the inverse of the standard error as a weight in the GLM models to give lesser weight to values that had higher uncertainty in their means (i.e., large standard errors; Zuur et al. 2009).

We compared means and 95\% confidence intervals (CIs) from DIN, $\mathrm{N}_{2}$ fixation rates, CHLA, and AFDM data from the 3 intensively sampled temporal sites and interpreted these results in the context of the broader gradient study. We used data from the temporal sites primarily as supporting evidence for the gradient-study results rather than as independent hypothesis tests about differences between the 3 sites.

\section{RESULTS}

\section{Spatial study}

DIN was strongly and positively related to catchmentscale $\%$ alder cover in May $\left(r^{2}=0.91, p<0.001\right.$; Fig. 2A) and August $\left(r^{2}=0.91, p<0.001\right.$; Fig. 2B). DIN concentrations were lowest at STAR-171 (11.6 and $4.0 \mu \mathrm{g} / \mathrm{L}$ in May

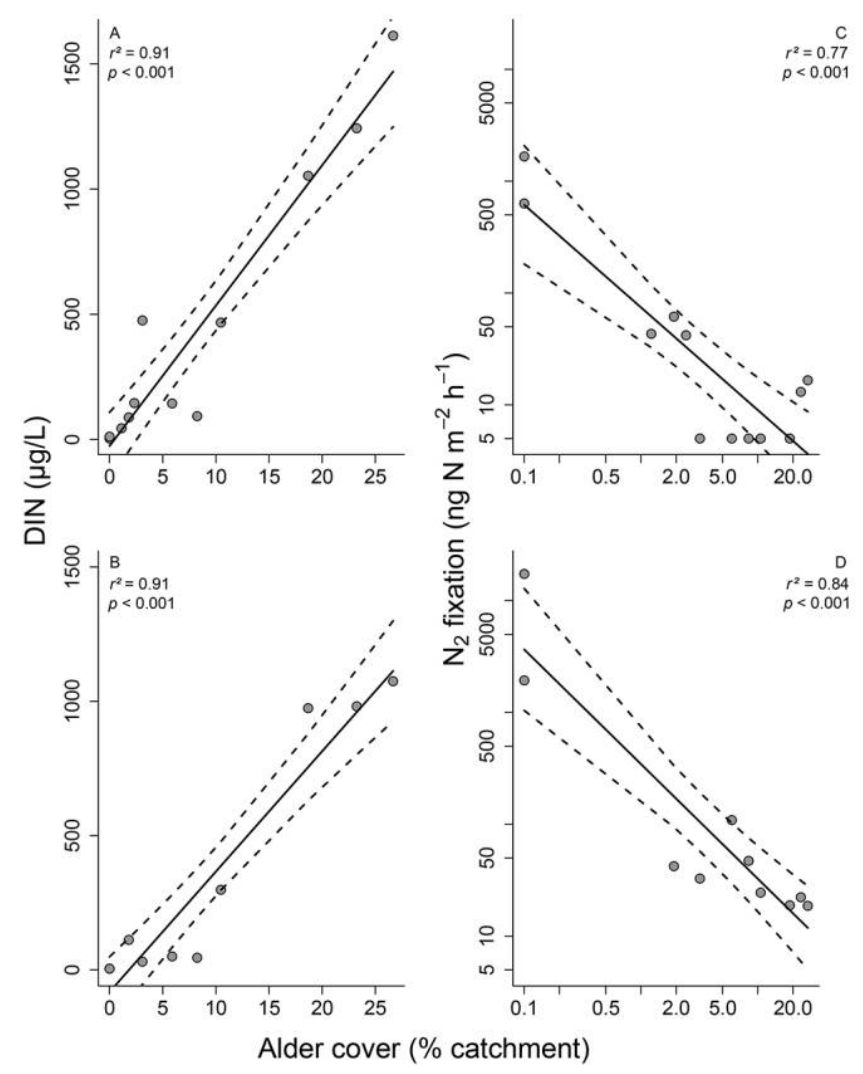

Figure 2. Relationship of dissolved inorganic N (DIN) (A, B) and $\mathrm{N}_{2}$ fixation rates $(\mathrm{C}, \mathrm{D})$ to alder cover (\%) in May (A, C) and August (B, D). Dashed lines represent $\pm 95 \%$ CI. 


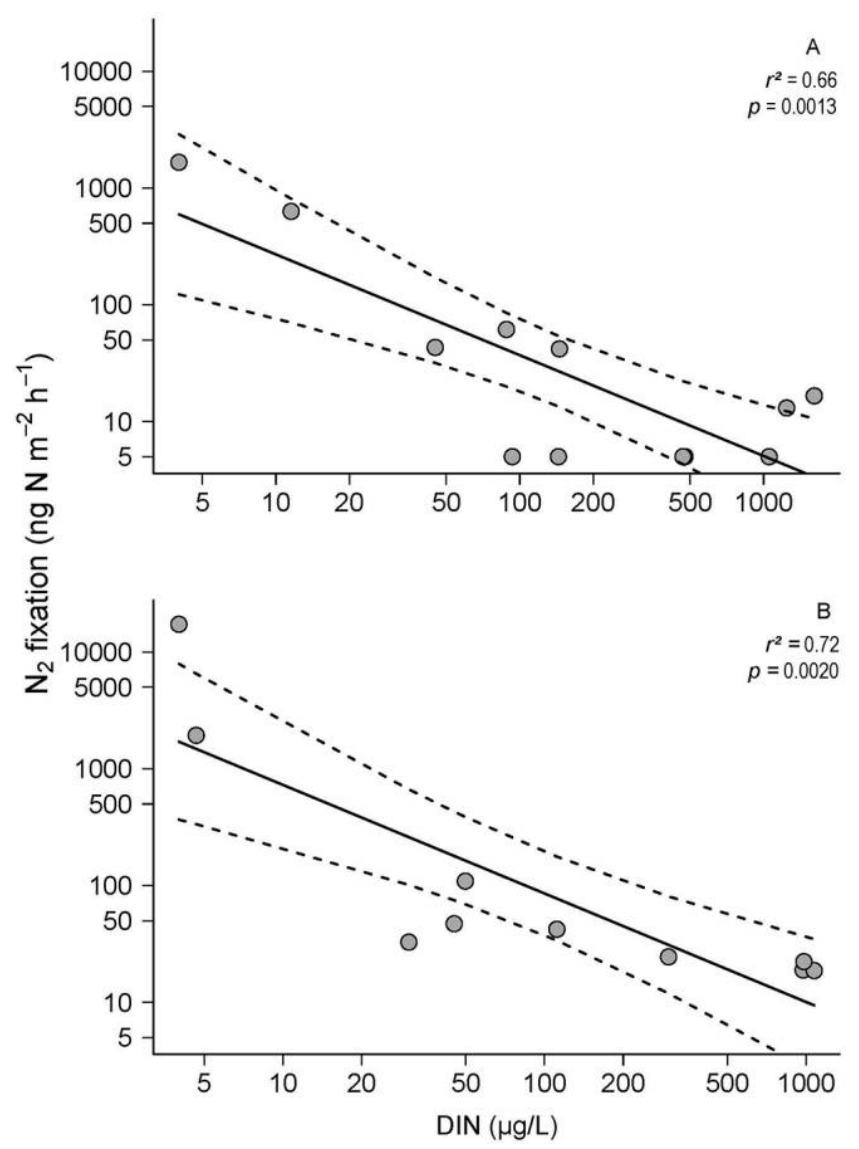

Figure 3. Relationship of $\mathrm{N}_{2}$ fixation rates with $\pm 95 \% \mathrm{CI}$ (dashed lines) and dissolved inorganic $\mathrm{N}$ (DIN) concentrations for May (A) and August (B), with all axes $\log _{10}(x)$-transformed.

and August, respectively) and DEEP-31 (4.0 and 4.7 $\mu \mathrm{g} / \mathrm{L}$ in May and August, respectively), which had the lowest \% alder cover (0\%), whereas DIN was highest at ANC-5 (1612.4 and $1074.5 \mu \mathrm{g} / \mathrm{L}$ in May and August, respectively), which had the highest \% alder cover.

$\mathrm{N}_{2}$ fixation rates were strongly negatively related to \% alder cover in May $\left(r^{2}=0.78, p<0.001\right.$; Fig. $\left.2 \mathrm{C}\right)$ and August $\left(r^{2}=0.84, p<0.001\right.$; Fig. $\left.2 \mathrm{D}\right)$, and this relationship was $\log -\log$ linear (i.e., very sharp declines in $\mathrm{N}_{2}$ fixation rates with low-level \% alder cover). Measured rates of $\mathrm{N}_{2}$ fixation declined from elevated (>500 ng $\left.\mathrm{N} \mathrm{m}^{-2} \mathrm{~h}^{-1}\right)$ in catchments with no alder to very low rates that were close to detection limits when $\%$ alder cover was $>\sim 2 \%$ (Fig. 2C, D). $\mathrm{N}_{2}$ fixation rates were negatively related to DIN in both May (May, $r^{2}=0.66, p=0.0013$; Fig. 3A) and August $\left(r^{2}=\right.$ $0.72, p=0.0020$; Fig. 3B). $\mathrm{N}_{2}$ fixation rates reflected similar trends seen with \% alder cover and declined sharply with increasing DIN. $\mathrm{N}_{2}$ fixation rates were near detection limits when DIN was $>\sim 20-40 \mu \mathrm{g} / \mathrm{L}$.

Neither CHLA nor AFDM showed significant responses to \% alder cover in May or August. AFDM had a weakly negative relationship with DIN only in August $\left(r^{2}=0.474, p=0.0179\right.$, data not shown), whereas CHLA was unrelated to DIN in either month.

\section{Temporal study}

The no-alder site had relatively low DIN, whereas the low- and high-alder sites had DIN that was higher in proportion to the $\%$ alder cover in the catchment (Fig. 4A). The no-alder site had a steady increase in $\mathrm{N}_{2}$ fixation rates over the course of our sampling period, with qualitatively higher $\mathrm{N}_{2}$ fixation rates in August than in May (Fig. 4B). DIN concentration decreased at the no-alder site over the over this same period. Meanwhile, $\mathrm{N}_{2}$ fixation rates were at or near our detection limits $\left(5 \mathrm{ng} \mathrm{N} \mathrm{m}^{-2} \mathrm{~h}^{-1}\right)$ at the lowand high-alder sites (Fig. 4B).

AFDM and CHLA values did not change in a consistent pattern over the growing season among the 3 temporally intensive sites (Fig. 5A, B). AFDM remained $<1 \mathrm{mg} / \mathrm{cm}^{2}$ at the low- and high-alder sites throughout the temporal study, but was more variable and reached $\sim 2 \mathrm{mg} / \mathrm{cm}^{2}$ at the no-alder site (Fig. 5A). In contrast, CHLA tended to
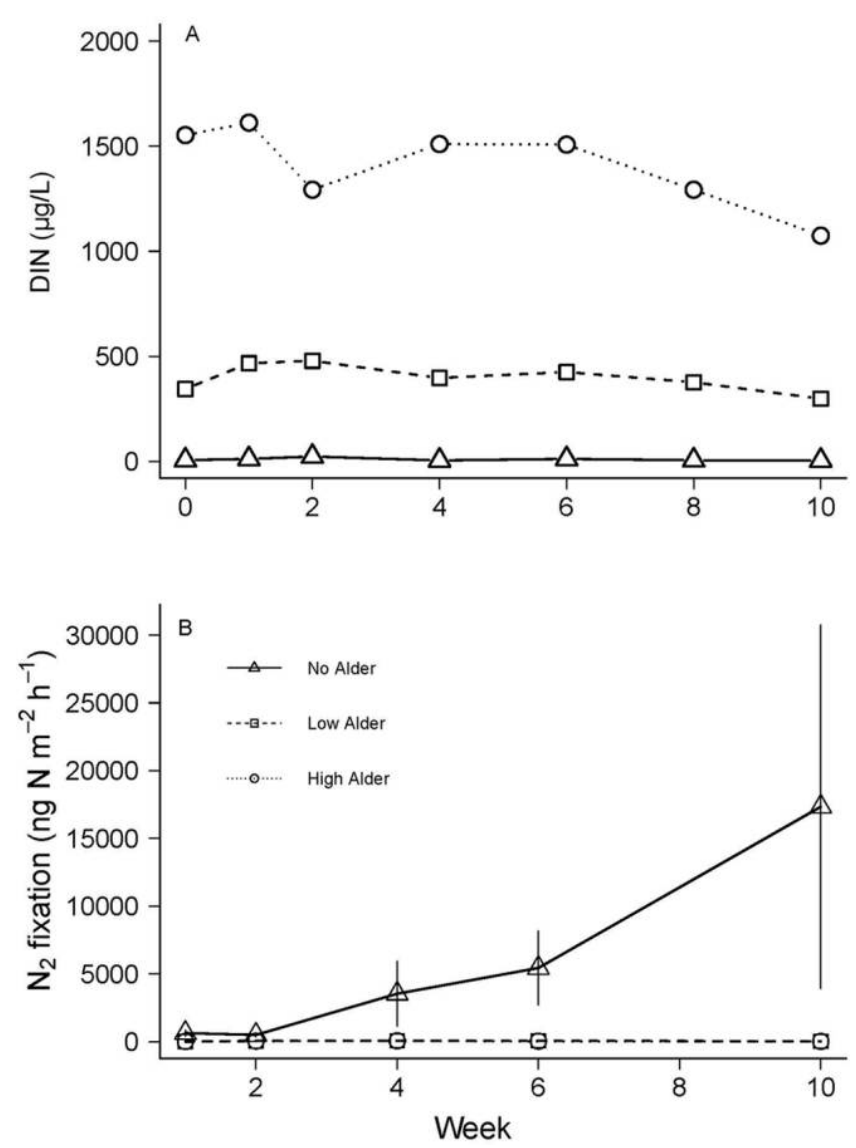

Figure 4. Dissolved inorganic N (DIN) (A) and mean $( \pm 95 \%$ CI) $\mathrm{N}_{2}$ fixation rates (B) through time for the 3 intensive temporal sampling sites (STAR-171, ANC-1203, ANC-5). Lines for the low- and high-\% alder cover sites overlap. 

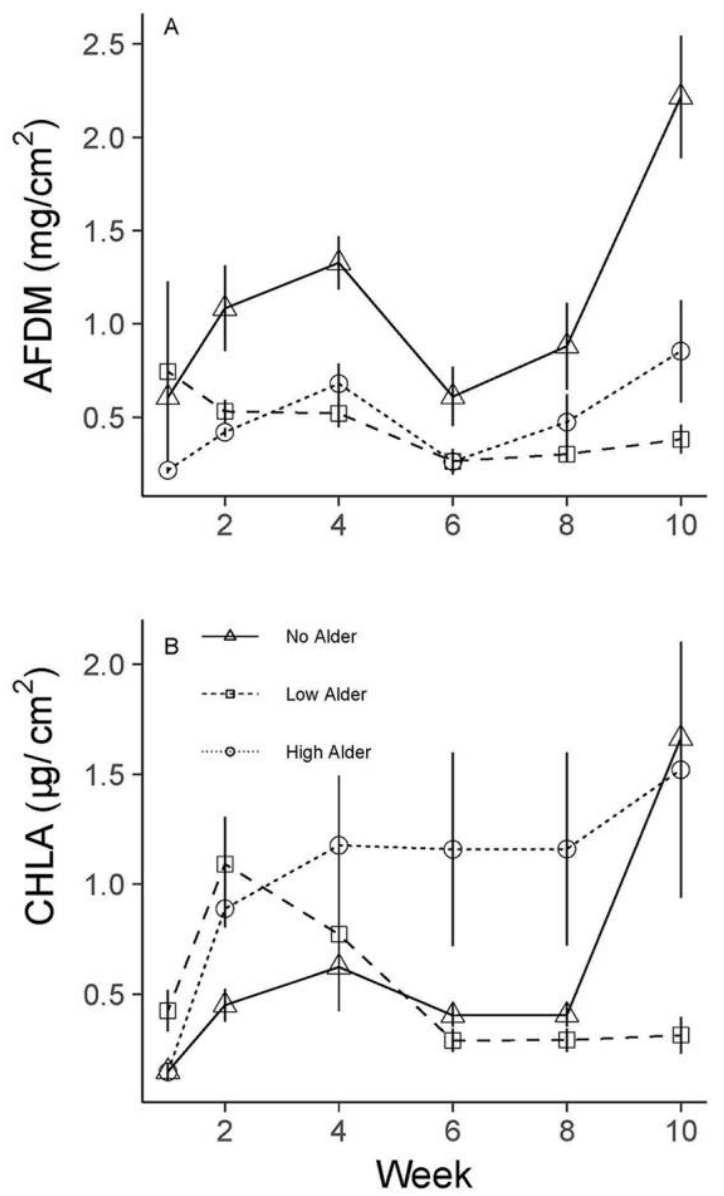

Figure 5. Mean ( $\pm 95 \% \mathrm{CI})$ ash-free dry mass (AFDM) (A) and chlorophyll $a$ (CHLA) (B) for the 3 intensive temporal sampling sites (STAR-171, ANC-1203, ANC-5).

be highest at the high-alder site, indicative of a higher number of autotrophs in the periphyton than at the noalder site (Fig. 5B).

\section{DISCUSSION}

Ecosystem level controls on $\mathrm{N}_{2}$ fixation are rarely assessed but must be evaluated for a complete understanding of N cycling (Vitousek et al. 2002, DeLuca et al. 2008). We observed that $\mathrm{N}_{2}$ fixation shifted spatially from the terrestrial landscape to the stream with decreasing alder. We observed that $\mathrm{N}_{2}$ fixation rates in stream periphyton declined across a gradient of increasing DIN, driven by an increasing gradient of $\%$ alder cover (i.e., terrestrial $\mathrm{N}_{2}$ fixation). Our results highlight a strong linkage between \% alder cover, in-stream DIN concentrations, and $\mathrm{N}_{2}$ fixation rates, which demonstrates that catchment alder can control in-stream $\mathrm{N}_{2}$ fixation rates and could influence other processes linked to stream $\mathrm{N}$ cycling.

$\mathrm{N}_{2}$ fixation is infrequently measured in stream ecosystems (Marcarelli et al. 2008). The vast majority of $\mathrm{N}_{2}$ fixa- tion measurements in our study are low in comparison to literature values, and are $<10 \mu \mathrm{g} \mathrm{N} \mathrm{m}{ }^{-2} \mathrm{~h}^{-1}$, the median value reported by Marcarelli et al. (2008). The average $\mathrm{N}_{2}$ fixation rate we measured was $0.894 \mu \mathrm{g} \mathrm{N} \mathrm{m}{ }^{-2} \mathrm{~h}^{-1}$ and the median rate was $0.038 \mu \mathrm{g} \mathrm{N} \mathrm{m}{ }^{-2} \mathrm{~h}^{-1}$. We measured $\mathrm{N}_{2}$ fixation rates across a DIN gradient associated with \% alder cover, so we did not choose sites that had universally low DIN and an associated expectation of high $\mathrm{N}_{2}$ fixation rates, as has been suggested for a bias in $\mathrm{N}_{2}$ fixation rates in the literature (Marcarelli et al. 2008). Temperatures in south-central Alaska headwater streams rarely are $>10^{\circ} \mathrm{C}$, which is colder than streams used in most $\mathrm{N}_{2-}$ fixation studies (e.g., Scott et al. 2009, Lang et al. 2012, Kunza and Hall 2013, 2014, reviewed by Marcarelli et al. 2008). This low temperature could lead to low biomass accumulation, favor non- $\mathrm{N}_{2}$-fixing communities, and physiologically limit $\mathrm{N}_{2}$ fixation rates (Marcarelli and Wurtsbaugh 2006). Marcarelli and Wurtsbaugh (2009) reported rates of $\mathrm{N}_{2}$ fixation $\left(\sim 1 \mu \mathrm{g} \mathrm{N} \mathrm{m}{ }^{-2} \mathrm{~h}^{-1}\right)$ similar to ours in epilithic periphyton in a lake-inlet stream of similar temperature and DIN concentrations to our study streams that were similar to rates at our low-DIN sites. Thus, high DIN concentrations and low temperatures explain relatively low $\mathrm{N}_{2}$ fixation rates relative to literature reports.

Measuring $\mathrm{N}_{2}$ fixation across a DIN gradient allowed us to assess $\mathrm{N}_{2}$ fixation rates as an explicit function of DIN concentrations. In contrast, the influence of DIN concentrations on $\mathrm{N}_{2}$ fixation rates has been examined primarily based on comparisons between background $\mathrm{N}_{2}$ fixation rates and $\mathrm{N}_{2}$ fixation rates corresponding to an unspecified increase in $\mathrm{N}$ availability on nutrient-diffusing substrates. We found that $\mathrm{N}_{2}$ fixation rates were low or undetectable when DIN was $>20$ to $40 \mu \mathrm{g} / \mathrm{L}$. This finding agrees with that of Kunza and Hall (2014), who found that $\mathrm{N}_{2}$ fixation rates in Wyoming streams were low or undetectable at DIN concentrations $>20 \mu \mathrm{g} / \mathrm{L}$. Mean $\mathrm{N}_{2}$ fixation rates in our study streams were very low in August but were never below detection limits. Slightly higher temperatures in August could have been favorable for the inclusion of $\mathrm{N}_{2}$-fixing cyanobacteria, leading to detectable rates of $\mathrm{N}_{2}$ fixation. In addition, stream DIN concentrations were lower in August than in May, which could imply that greater demand for inorganic $\mathrm{N}$ and decreased supply because of terrestrial uptake ultimately increased $\mathrm{N}_{2}$ fixation rates. Nearly all $\mathrm{NO}_{3} / \mathrm{NO}_{2}-\mathrm{N}$ concentrations decreased from May to August, and we observed a gradual decrease throughout the temporal study in the high-alder site (ANC-5; Table 1, Fig. 4A). In the most extreme example, one stream (ANC3; Table 1) decreased from $472 \mu \mathrm{g} \mathrm{NO}_{3} / \mathrm{NO}_{2}-\mathrm{N} / \mathrm{L}$ in May to $27 \mu \mathrm{g} \mathrm{NO} \mathrm{NO}_{3} / \mathrm{NO}_{2}-\mathrm{N} / \mathrm{L}$ in August. Shaftel et al. (2012) observed a similar pattern in some of the same streams, where some mid-level-alder sites had lower than expected DIN concentrations in July and September than in May. We suspect that increased temperature-driven uptake or summer 
low flows (i.e., reduced hydrologic connection) along soil flow paths decreased the amount of alder-derived $\mathrm{N}$ being exported to the streams (Callahan et al. 2017). Thus, $\mathrm{N}_{2}$ fixation rates in these streams could be sensitive to temperature or precipitation changes at the reach and catchment scales via controls on landscape DIN export. Moreover, chronic P enrichment can increase $\mathrm{N}_{2}$ fixation rates by decreasing the relative availability of $\mathrm{N}$ (Marcarelli and Wurtsbaugh 2006, 2007, Kunza and Hall 2013). In our study, $\mathrm{PO}_{4}-\mathrm{P}$ concentrations varied little, and concurrent alkaline phosphatase activity assays suggested little to no P limitation that was only driven by $\mathrm{PO}_{4}-\mathrm{P}$ concentration across all sites (DLH, unpublished data).

We expected to see greater biomass accumulation in the high-alder site because $\mathrm{N}$ can be acquired more efficiently from water-column DIN than through energetically demanding $\mathrm{N}_{2}$ fixation. Greater AFDM in the no-alder (i.e., low DIN) site compared to high- and low-alder sites might suggest that $\mathrm{N}_{2}$ fixation provided adequate $\mathrm{N}$ to facilitate greater periphyton growth, but alternate explanations exist for this pattern. In particular, periphyton biomass could have been sloughed or grazed at different rates among our sites. Shaftel et al. (2012) observed greater shredder colonization of leaf litter in high-DIN streams in this region. Increased alder cover driving high in-stream DIN could have resulted in accelerated periphyton growth, but a potential increase in grazer abundances, similar to the observation by Shaftel et al. (2012) of increased shredders in leaf packs, could have suppressed actual biomass accumulation. In addition, CHLA responses were inconsistent and, at most, could suggest that high DIN contributed to greater autotroph biomass. AFDM increases without corresponding CHLA response may indicate that differences in biomass trends are being driven by heterotrophic microbes, leaving open the possibility that dissolved organic C (DOC) availability at the no-alder site increased heterotrophic microbial biomass production. The low-alder site drains wetlands, which provide significantly more DOC than at sites that typically have high \% alder in their catchments (Walker et al. 2012). The possibility that $\mathrm{N}_{2}$ fixation compensates for low $\mathrm{N}$ availability in streams warrants direct experimentation (Dodds and Smith 2016), but we cannot conclusively estimate the influence of $\%$ alder cover on periphyton biomass from our data.

Most northern-latitude actinorhizal trees, including alder, probably exhibit obligate $\mathrm{N}_{2}$ fixation-they do not regulate $\mathrm{N}_{2}$ fixation rates based on soil $\mathrm{N}$ availability-as opposed to facultative $\mathrm{N}_{2}$ fixation (Menge et al. 2014). Obligate fixers alter terrestrial $\mathrm{N}$ inputs purely by their presence, i.e., as a function of plant community dynamics (Menge et al. 2009). How do terrestrial symbiotic $\mathrm{N}_{2}$ fixation strategies compare to periphyton $\mathrm{N}_{2}$ fixation strategies? Evidence suggests that periphyton $\mathrm{N}_{2}$ fixation rates are insensitive to changes in $\mathrm{N}$ concentrations (i.e., obli- gate) on time scales of several hours (Kunza and Hall 2013). However, cyanobacterial cultures may downregulate $\mathrm{N}_{2}$ fixation rates in response to inorganic $\mathrm{N}$ addition over similar time periods (Meeks et al. 1983). Periphyton $\mathrm{N}_{2}$ fixation rates also appear to be strongly regulated by community composition because $\mathrm{N}_{2}$ fixation is carried out by specialized taxa or their endosymbionts (Marcarelli and Wurtsbaugh 2006, Kunza and Hall 2013). Community dynamics for stream periphyton are much shorter than for terrestrial plant communities, so changes in aquatic $\mathrm{N}$ conditions from alder cover probably control periphyton $\mathrm{N}_{2}$ fixer community composition. Community (demographic) vs physiologic downregulation effects of $\mathrm{N}$ on $\mathrm{N}_{2}$ fixation rates are understudied in periphyton (but see Kunza and Hall 2013), obscuring the use of 'obligate' or 'facultative' terminology for periphyton communities. Whatever the exact regulatory mechanism, periphyton across our alder gradient appeared to be spatially facultative, with regulatory feedback coming from alder-derived $\mathrm{N}$.

Because alder is an obligate $\mathrm{N}_{2}$ fixer, landscape cover and distance from streams (length of soil flow path) determine N delivery from alder to streams (Shaftel et al. 2012, Callahan et al. 2017). Alder presence can be a robust predictor of $\mathrm{N}$ availability in areas with minimal anthropogenic $\mathrm{N}$ sources. In our study, relatively low catchment coverage $(>2 \%)$ led to elevated DIN concentrations and strong suppression of aquatic $\mathrm{N}_{2}$ fixation rates, suggesting that low alder abundance can strongly influence aquatic $\mathrm{N}$ cycling. Therefore, alder or presence of other $\mathrm{N}_{2}$-fixing organisms in catchments (e.g., DeLuca et al. 2013) may be a critical control on aquatic $\mathrm{N}$ cycling across traditional ecosystem boundaries (aquatic-terrestrial), supporting a meta-ecosystem approach to studying terrestrial subsidies to streams (Soininen et al. 2015).

Tight control over a frequently limiting nutrient suggests that terrestrial alder could conceivably influence other stream ecosystem processes. Biofilms in other boreal streams can be $\mathrm{N}$ limited (Burrows et al. 2015). This N limitation could be alleviated and tightly controlled at the catchment scale by alder via $\mathrm{N}$ inputs to streams. We found inconclusive evidence of alder influence over periphyton biomass. Moreover, litter breakdown rates and macroinvertebrate colonization can be controlled by alder-derived DIN (Shaftel et al. 2011). Other aspects of stream structure and function (e.g., periphyton tissue stoichiometry, community composition, whole-stream metabolism) have yet to be examined in light of this alder-stream connection.

Landscape control of $\mathrm{N}_{2}$ fixation has several implications under projected regional and global change. As the distribution of alder expands in boreal regions (Hiltbrunner et al. 2014), the $\mathrm{N}$ budgets of landscapes and associated catchment waters may be significantly altered, which could have consequences for productivity of economically important juvenile salmonid food webs. If alder are lost from 
the catchment, as is occurring in some riparian species because of fungal disease (Bjelke et al. 2016), energetic costs of $\mathrm{N}_{2}$ fixation may shift from the landscape to the stream. In addition, climate change probably will interact with alder and associated $\mathrm{N}$ export to, and cycling within, streams (Greaver et al. 2016). With climate warming, N uptake might increase along terrestrial flowpaths, effectively decreasing the amount of DIN exported to streams. Changing patterns of rainfall could alter hydrologic connectivity of alder and streams (Covino 2017). Alder presence also may set the primary environmental context determining the degree to which stream $\mathrm{N}$ cycling and primary production are coupled under different warming scenarios (Welter et al. 2015, Williamson et al. 2016). The influence of anthropogenic $\mathrm{N}$ subsidies has received rightful attention, but the influence of $\mathrm{N}_{2}$-fixing terrestrial plant subsidies to streams requires further study because of broad implications for $\mathrm{N}$ cycling and budgets.

\section{ACKNOWLEDGEMENTS}

Author contributions: DLH, RSK, RDD, DFW, MCR, and CMW designed the overall study. DLH, RSK, RDD, JAB, and PKK collected and analyzed data. DLH, CRR, RSK, RDD, and JAB wrote and provided much of the basis for the paper. DFW, PKK, MCR, and CMW provided editorial comments throughout each iteration phase of the paper.

We thank the Center for Reservoir and Aquatic Systems Research (CRASR) laboratory at Baylor University for performing water-chemistry analyses, Rebecca Shaftel for catchment area and alder cover estimates, and Terry Thompson, Angela Doroff, Kim Cooney, Amy Alderfer, Jasmine Maurer, and Steve Baird at the Kachemak Bay Research Reserve for providing logistical support, assistance in the field, transportation, and housing. Funding was provided by the Jack G. and Norma Jean Folmar Research Fund, the C. Gus Glasscock, Jr. Endowed Fund for Excellence in Environmental Sciences in the College of Arts and Sciences at Baylor University, and a grant from the Alaska Sustainable Salmon Fund (11244709).

\section{LITERATURE CITED}

Allan, J. D., and M. M. Castillo. 2007. Stream ecology: structure and function of running waters. Springer Science and Business Media, Dordrecht, The Netherlands.

Biggs, B. J., and C. Kilroy. 2000. Stream periphyton monitoring manual. National Institute of Water and Atmospheric Research, Auckland, New Zealand. (Available from: https:// www.niwa.co.nz/sites/niwa.co.nz/files/import/attachments /peri_complete.pdf)

Bjelke, U., J. Boberg, J. Oliva, K. Tattersdill, and B. G. McKie. 2016. Dieback of riparian alder caused by the Phytophthora alni complex: projected consequences for stream ecosystems. Freshwater Biology 61:565-579.

Bühlmann, T., C. Körner, and E. Hiltbrunner. 2016. Shrub expansion of Alnus viridis drives former montane grassland into nitrogen saturation. Ecosystems 19:968-985.
Burrows, R. M., E. R. Hotchkiss, M. Jonsson, H. Laudon, B. G. McKie, and R. A. Sponseller. 2015. Nitrogen limitation of heterotrophic biofilms in boreal streams. Freshwater Biology 60: 1237-1251.

Callahan, M. K., M. C. Rains, D. F. Whigham, K. Rains, C. M. Walker, J. Maurer, S. Baird, and R. S. King. 2017. Nitrogen subsidies from hillslope alder stands to streamside wetlands and headwater streams, Kenai Peninsula, Alaska. Journal of the American Water Resources Association. doi:10.1111 /1752-1688.12508.

Compton, J. E., M. R. Church, S. T. Larned, and W. E. Hogsett. 2003. Nitrogen export from forested watersheds in the Oregon Coast Range: the role of $\mathrm{N}_{2}$-fixing red alder. Ecosystems 6:773-785.

Covino, T. 2017. Hydrologic connectivity as a framework for understanding biogeochemical flux through watersheds and along fluvial networks. Geomorphology 277:133-144.

DeLuca, T. H., O. Zackrisson, I. Bergman, B. Díez, and B. Bergman. 2013. Diazotrophy in alluvial meadows of subarctic river systems. PLoS ONE 8:e77342.

DeLuca, T. H., O. Zackrisson, M. J. Gundale, and M. C. Nilsson. 2008. Ecosystem feedbacks and nitrogen fixation in boreal forests. Science 320:1181.

Dodds, W. K., and V. H. Smith. 2016. Nitrogen, phosphorus, and eutrophication in streams. Inland Waters 6:155-164.

Dugdale, R. C., and V. A. Dugdale. 1961. Sources of phosphorus and nitrogen for lakes on Afognak Island. Limnology and Oceanography 6:13-23.

Edmonds, R. L., and K. M. Tuttle. 2010. Red alder leaf decomposition and nutrient release in alder and conifer riparian patches in western Washington, USA. Forest Ecologv and Management 259:2375-2381.

Flett, R. J., R. D. Hamilton, and N. E. R. Campbell. 1976. Aquatic acetylene-reduction techniques: solutions to several problems. Canadian Journal of Microbiology 22:43-51.

Gracz, M., and P. H. Glaser. 2016. Evaluation of a wetland classification system devised for management in a region with a high cover of peatlands: an example from the Cook Inlet Basin, Alaska. Wetlands Ecology and Management 25:1-18.

Greaver, T. L., C. M. Clark, J. E. Compton, D. Vallano, A. F. Talhelm, C. P. Weaver, L. E. Band, J. S. Baron, E. A. Davidson, C. L. Tague, E. Felker-Quinn, J. A. Lynch, J. D. Herrick, L. Liu, C. L. Goodale, K. J. Novak, and R. A. Haeuber. 2016. Key ecological responses to nitrogen are altered by climate change. Nature Climate Change 6:836-843.

Hiltbrunner, E., R. Aerts, T. Bühlmann, K. Huss-Danell, B. Magnusson, D. D. Myrold, S. C. Reed, B. D. Sigurdsson, and C. Körner. 2014. Ecological consequences of the expansion of $\mathrm{N}_{2}$-fixing plants in cold biomes. Oecologia 176:11-24.

Howarth, R. W., R. Marino, J. J. Cole, and J. Lane. 1988. Nitrogen fixation in freshwater, estuarine, and marine ecosystems. 2. Biogeochemical controls. Limnology and Oceanography 33: 688-701.

Kunza, L. A., and R. O. Hall. 2013. Demographic and mutualistic responses of stream nitrogen fixers to nutrients. Freshwater Science 32:991-1004.

Kunza, L. A., and R. O. Hall. 2014. Nitrogen fixation can exceed inorganic nitrogen uptake fluxes in oligotrophic streams. Biogeochemistry 121:537-549. 
Lang, D. A., R. S. King, and J. T. Scott. 2012. Divergent responses of biomass and enzyme activities suggest differential nutrient limitation in stream periphyton. Freshwater Science 31:10961104.

LeBauer, D. S., and K. T. Treseder. 2008. Nitrogen limitation of net primary productivity in terrestrial ecosystems is globally distributed. Ecology 89:371-379.

Marcarelli, A. M., M. A. Baker, and W. A. Wurtsbaugh. 2008. Is in-stream $\mathrm{N}_{2}$ fixation an important $\mathrm{N}$ source for benthic communities and stream ecosystems? Journal of the North American Benthological Society 27:186-211.

Marcarelli, A. M., and W. A. Wurtsbaugh. 2006. Temperature and nutrient supply interact to control nitrogen fixation in oligotrophic streams: an experimental examination. Limnology and Oceanography 51:2278-2289.

Marcarelli, A. M., and W. A. Wurtsbaugh. 2007. Effects of upstream lakes and nutrient limitation on periphytic biomass and nitrogen fixation in oligotrophic, subalpine streams. Freshwater Biology 52:2211-2225.

Marcarelli, A. M., and W. A. Wurtsbaugh. 2009. Nitrogen fixation varies spatially and seasonally in linked stream-lake ecosystems. Biogeochemistry 94:95-110.

Meeks, J. C., K. L. Wycoff, J. S. Chapman, and C. S. Enderlin. 1983. Regulation of expression of nitrate and dinitrogen assimilation by Anabaena species. Applied and Environmental Microbiology 45:1351-1359.

Menge, D. N., S. A. Levin, and L. O. Hedin. 2009. Facultative versus obligate nitrogen fixation strategies and their ecosystem consequences. American Naturalist 174:465-477.

Menge, D. N., J. W. Lichstein, and G. Ángeles-Pérez. 2014. Nitrogen fixation strategies can explain the latitudinal shift in nitrogen-fixing tree abundance. Ecology 95:2236-2245.

Mineau, M. M., C. V. Baxter, and A. M. Marcarelli. 2011. A nonnative riparian tree (Elaeagnus angustifolia) changes nutrient dynamics in streams. Ecosystems 14:353-365.

Ping, C. L., and G. J. Michaelson. 1986. Phosphorus sorption by major agricultural soils of Alaska. Communications in Soil Science and Plant Analysis 17:299-320.

Polis, G. A., W. B. Anderson, and R. D. Holt. 1997. Toward an integration of landscape and food web ecology: the dynamics of spatially subsidized food webs. Annual Review of Ecology and Systematics 28:289-316.

Reynolds, K. M. 1990. Preliminary classification of forest vegetation of the Kenai Peninsula, Alaska. Research Paper PNW-RP424. Pacific Northwest Research Station, US Department of Agriculture Forest Service, Portland, Oregon.

Rothe, A., K. Cromack, S. C. Resh, E. Makineci, and Y. Son. 2002. Soil carbon and nitrogen changes under Douglas-fir with and without red alder. Soil Science Society of America Journal 66: 1988-1995.
Scott, J. T., D. A. Lang, R. S. King, and R. D. Doyle. 2009. Nitrogen fixation and phosphatase activity in periphyton growing on nutrient diffusing substrata: evidence for differential nutrient limitation in stream periphyton. Journal of the North American Benthological Society 28:57-68.

Shaftel, R. S., R. S. King, and J. A. Back. 2011. Breakdown rates, nutrient concentrations, and macroinvertebrate colonization of bluejoint grass litter in headwater streams of the Kenai Peninsula, Alaska. Journal of the North American Benthological Society 30:386-398.

Shaftel, R. S., R. S. King, and J. A. Back. 2012. Alder cover drives nitrogen availability in Kenai lowland headwater streams, Alaska. Biogeochemistry 107:135-148.

Sobota, D. J., J. E. Compton, and J. A. Harrison. 2013. Reactive nitrogen inputs to US lands and waterways: how certain are we about sources and fluxes. Frontiers in Ecology and the Environment 11:82-90.

Soininen, J., P. Bartels, J. Heino, M. Luoto, and H. Hillebrand. 2015. Toward more integrated ecosystem research in aquatic and terrestrial environments. BioScience 65:174-182.

Stottlemyer, R., and D. Toczydlowski. 1999. Seasonal relationships between precipitation, forest floor, and stream water nitrogen, Isle Royale, Michigan. Soil Science Society of America Journal 63:389-398.

Viereck, L. A., C. T. Dyrness, A. R. Batten, and K. J. Wenzlick. 1992. The Alaska vegetation classification. General Technical Report PNW-GTR-286. Pacific Northwest Research Station, US Department of Agriculture Forest Service, Portland, Oregon.

Vitousek, P. M., K. Cassman, C. Cleveland, T. Crews, C. B. Field, N. B. Grimm, R. W. Howarth, R. Marino, L. Martinelli, E. B. Rastetter, and J. I. Sprent. 2002. Towards an ecological understanding of biological nitrogen fixation. Biogeochemistry $57-$ 58:1-45.

Walker, C. M., R. S. King, D. F. Whigham, and S. J. Baird. 2012. Landscape and wetland influences on headwater stream chemistry in the Kenai Lowlands, Alaska. Wetlands 32:301310.

Welter, J. R., J. P. Benstead, W. F. Cross, J. M. Hood, A. D. Huryn, P. W. Johnson, and T. J. Williamson. 2015. Does $\mathrm{N}_{2}$ fixation amplify the temperature dependence of ecosystem metabolism? Ecology 96:603-610.

Williamson, T. J., W. F. Cross, J. P. Benstead, G. M. Gíslason, J. M. Hood, A. D. Huryn, P. W. Johnson, and J. R. Welter. 2016. Warming alters coupled carbon and nutrient cycles in experimental streams. Global Change Biology 22:21522164.

Zuur, A. F., E. N. Ieno, N. Walker, A. A. Saveliev, and G. M. Smith. 2009. Mixed effects models and extensions in ecology with R. Springer-Verlag, New York. 